\title{
Perbandingan TAI dan NHT terhadap Hasil Belajar Trigonometri Ditinjau dari Kecerdasan Interpersonal
}

\author{
Yoga Setiawan ${ }^{*}$ dan Erlina Prihatnani ${ }^{2}$ \\ 1*,2 Program Studi Pendidikan Matematika, Universitas Kristen Satya Wacana \\ Jalan Diponegoro No. 52-60, Salatiga, Jawa Tengah, Indonesia \\ 1202016014@student.uksw.edu, 2erlina.prihatnani@uksw.edu
}

Artikel diterima: 03-12-2019, direvisi: 27-05-2020, diterbitkan: 31-05-2020

\begin{abstract}
Abstrak
Setiap model pembelajaran kooperatif memiliki karakteristik dalam menerapkan enam prinsip pembelajaran kooperatif termasuk model Team Assisted Individualization (TAI) dan Numbered Heads Together (NHT). Tujuan penelitian ini untuk mengetahui manakah yang menghasilkan hasil belajar yang lebih baik diantara (1) model TAI dan NHT, (2) tingkat kecerdasan interpersonal, dan (3) interaksi model pembelajaran TAI dan NHT dengan kecerdasan interpersonal. Populasi penelitian adalah seluruh siswa kelas X SMA N 1 Salatiga Tahun Ajaran 2018/2019 (384 siswa). Melalui teknik cluster random sampling diperoleh 30 siswa kelas X IPS 1 sebagai kelas eksperimen 1 dan 34 siswa kelas $X$ IPS 2 sebagai kelas eksperimen 2 dengan perbedaan perlakuan dalam pembelajaran trigonometri. Penelitian eksperimen semu ini menggunakan randomized control group pretest-postest design. Uji hipotesis menyimpulkan (1) hasil belajar siswa dengan model TAI secara signifikan lebih baik daripada NHT, (2) tidak ada perbedaan hasil belajar yang signifikan dari tingkat kecerdasan interpersonal yang berbeda, (3) tidak terdapat interaksi antara model pembelajaran dengan kecerdasan interpersonal terhadap hasil belajar. Kata Kunci: TAl, NHT, pembelajaran kooperatif, kecerdasan interpersonal, hasil belajar, trigonometri.
\end{abstract}

\section{The Comparison of TAl and NHT Towards Students' Achievement on Trigonometry Reviewed from Interpersonal Intelligence}

\section{Abstract}

Each type of cooperative learning model has different characteristics in applying 6 principles of cooperative learning, including TAl (Team Assisted Individualization) and NHT (Numbered Head Together) type models. This study aimed to find out: (1) which learning outcomes are better between students using the TAI or NHT models, (2) which learning outcomes are better between students with high, medium and low interpersonal intelligence levels, (3) is there any correlation between TAI and NHT learning models with interpersonal intelligence on student learning outcomes. The population in this study were all students of $X$ grade at SMA N 1 Salatiga in the Academic Year 2018/2019 (384 students). Through assembling random sampling techniques obtained students of class X IPS 1 (30 students) as experimental class I and students of class X IPS 2 (34 students) as experimental class II with different treatment in learning mathematics on trigonometry material. This quasi-experimental research used a randomized control group pretest-posttest design. Hypothesis test results concluded that (1) student learning outcomes with the TAI model were significantly better than student learning outcomes with the NHT model, (2) there was no significant difference between student learning outcomes of different levels of interpersonal intelligence, (3) there were no interactions between models learning with interpersonal intelligence on student learning outcomes.

Keywords: TAl, NHT, cooperative learning, interpersonal intelligence, learning outcomes, trigonometry. 


\section{Pendahuluan}

Matematika mempunyai peran yang penting dalam kehidupan sehari-hari serta dalam pengembangan ilmu pengetahuan lain. Oleh karena itu, matematika disebut sebagai "Ratu sekaligus pelayan IImu Pengetahuan" (Suherman, 2001). Oleh sebab itu, penting bagi siswa untuk menguasai materi dalam pembelajaran matematika di sekolah agar dapat menggunakannya dalam kehidupan sehari-hari. Namun demikian, pembelajaran matematika di Indonesia masih belum maksimal (Afriansyah, 2015).

Menurut (Lie, 2002), banyak kegiatan belajar mengajar yang dilakukan oleh guru yang sekedar memindahkan pengetahuan dari guru ke siswa, dimana guru berperan sebagai sumber informasi dan siswa berperan sebagai pihak penerima. Proses pembelajaran tersebut tidak sesuai dengan standar proses pembelajaran yang tertuang dalam Permendikbud nomor 22 tahun 2016 yang menyebutkan bahwa proses pembelajaran salah satunya harus dilaksanakan secara interaktif dan memotivasi peserta didik untuk berperan aktif.

Salah satu prinsip pembelajaran K13 adalah dari peserta didik diberi tahu menuju peserta didik mencari tahu, dari guru sebagai satu-satunya sumber belajar menjadi belajar berbasis aneka sumber belajar. Ketetapan yang terdapat pada Permendikbud nomor 22 tahun 2016 ini menekankan pembelajaran yang berfokus pada siswa sehingga tercipta proses pembelajaran yang dapat memfasilitasi siswa untuk mengkonstruksi pengetahuan. Oleh karena itu, diperlukan model pembelajaran yang sesuai dengan standar proses salah satunya adalah Cooperative Learning (pembelajaran kooperatif).
Menurut (Slavin, 2005), pembelajaran kooperatif adalah model pembelajaran yang memberikan kesempatan pada siswa untuk bekerja dalam kelompok-kelompok kecil untuk saling membantu satu sama lainnya dalam mempelajari materi pelajaran. Putri (2018) mengungkapkan bahwa semua metode yang dilakukan pada model pembelajaran kooperatif memberikan kesempatan kepada siswa dengan komunitas kelasnya untuk menemukan pengetahuan bersama. Lebih lanjut (Slavin, 2005) menyebutkan bahwa terdapat enam prinsip pembelajaran kooperatif yang harus ada dalam pelaksanaan pembelajaran kooperatif, yaitu adanya tujuan kelompok, tanggung jawab individu, kesempatan sukses yang sama, kompetisi kelompok, spesialisasi tugas, adaptasi terhadap kebutuhan kelompok. Terdapat berbagai tipe model pembelajaran kooperatif, diantaranya Team Assisted Individualization (TAI) dan Number Head Together (NHT). Kedua model ini mengandung 6 prinsip dalam pembelajaran kooperatif.

Langkah-langkah model pembelajaran NHT menurut Kagan (Asmani, 2012; Firdaus \& Afriansyah, 2016; Lagur, Makur, \& Ramda, 2018) adalah: siswa dibagi dalam kelompok dan setiap siswa dalam kelompok mendapat nomor, guru memberikan tugas kepada masing-masing kelompok untuk dikerjakan, kelompok mendiskusikan jawaban yang benar dan memastikan setiap anggota kelompok mengetahui jawabannya, guru memanggil salah satu nomor siswa dan nomor yang dipanggil melaporkan hasil diskusi kelompok, teman yang lain memberi tanggapan kemudian guru memanggil salah satu nomor lagi, siswa diajak untuk membuat kesimpulan. Berbeda dengan langkah NHT, langkah pembelajaran TAl adalah: 1) Placement Test, guru memberi tes awal kepada siswa 2) Teams, pada langkah ini guru 
membentuk kelompok-kelompok yang bersifat heterogen 3) Teaching Group, guru memberi materi singkat menjelang pemberian tugas kelompok 4) Student Creative, guru memberi tugas kelompok dan menekankan bahwa keberhasilan setiap siswa ditentukan oleh keberhasilan kelompoknya 5) Team Study, siswa bekerja bersama dalam kelompoknya dengan mendapat bantuan dari guru atau bantuan siswa yang mempunyai kemampuan akademis lebih bagus 6) Fact Test, guru memberikan tes yang dikerjakan secara individu 7) guru memberi skor pada hasil kerja kelompok 8) Whole-Class Units, guru menyajikan kembali materi di akhir bab dengan strategi pemecahan masalah untuk seluruh siswa di kelasnya (Shoimin, 2014; Riswanto, 2016).

Berdasarkan uraian langkah pembelajaran kedua model tersebut, tampak bahwa TAI dan NHT memiliki cara berbeda dalam menerapkan 6 prinsip pada cooperatif learning. Contohnya, jika dalam model TAl dilakukan tes individu di akhir pembelajaran untuk mengukur pemahaman siswa, maka dalam NHT dilakukan melalui proses pemanggilan nomor secara acak oleh guru untuk menentukan siswa yang harus melaporkan hasil kerja kelompoknya.

Beberapa penelitian telah membandingkan hasil belajar dari penerapan kedua model tersebut baik dalam jenjang pembelajaran di SMP maupun di SMA. Contoh penelitian yang dilakukan pada jenjang SMP adalah penelitian Hanggara \& Jafri, (2016) terhadap siswa kelas VII SMP Tunas Baru Jin Seung Batam dan penelitian Anggoro (2015) pada siswa kelas 8 MTs Mu'allimin Muhammadiyah Yogyakarta. Adapun contoh yang dilakukan pada jenjang SMA adalah penelitian Antoro \& Utomo (2016) pada siswa kelas XI IPA SMA N 3 Boyolali pada materi pokok sistem koloid dan penelitian Pradipta (2013) pada siswa XI IPA SMA N 1 Ngemplak boyolali dengan materi pokok kelarutan dan hasil kali kelarutan.

Meskipun demikian hasil dari keempat penelitian tersebut beragam. Penelitian Anggoro (2015) menyimpulkan bahwa tidak terdapat perbedaan hasil belajar yang signifikan antara TAI dan NHT sedangkan penelitian Pradipta (2013) menyimpulkan bahwa terdapat interaksi antara penerapan model TAI dan NHT terhadap hasil belajar siswa. Seperti halnya hasil penelitian Pradipta, hasil penelitian Antoro \& Utomo (2016) serta Hanggara \& Jafri, (2016) juga memperoleh hasil bahwa terdapat interaksi yang signifikan. Namun keduanya memiliki hasil yang berbeda. Penelitian Antoro \& Utomo (2016) menyimpulkan bahwa bahwa penerapan TAI menghasilkan hasil belajar yang lebih baik sedangkan penelitian Hanggara \& Jafri (2016) menyimpulkan bahwa penerapan NHT yang menghasilkan hasil belajar yang lebih baik.

Beberapa faktor dapat juga mempengaruhi pencapaian hasil belajar dari penerapan kedua model pembelajaran yang berbeda. Kedua model ini menuntut adanya interaksi di dalam kelompok, oleh karena itu keberhasilan model ini juga dimungkinkan dipengaruhi oleh kemampuan interaksi siswa dalam bekerja secara kelompok. Kemampuan interaksi siswa dengan siswa yang lain ini oleh Howard Gardner (2003: 24) disebut kecerdasan antar pribadi (interpersonal). Sejalan dengan pendapat tersebut, Said \& Budimanjaya (2015) mendefinisikan kecerdasan interpersonal sebagai kemampuan memahami dan berinteraksi dengan orang lain secara efektif dan kemampuan mempertahankan hubungan yang sudah terjalin sebelumnya. Said \& 
Budimanjaya (2015) menyebutkan bahwa ciriciri orang dengan kecerdasan interpersoanal baik ialah mempunyai kemampuan bergaul dengan orang lain, mempunyai kepekaan sosial dan empati yang tinggi, mampu bekerjasama.

Beberapa penelitian telah meneliti tentang bagaimana pengaruh kecerdasan interpersonal terhadap hasil belajar. Diantaranya penelitian yang dilakukan oleh Eka \& Nuriah (2017) terhadap siswa SMA Negeri 3 Kabupaten Tangerang pada materi sejarah, serta penelitian (Fajriani \& Masni, 2017) terhadap siswa kelas X SMA Negeri se Kabupaten Bulukumba. Kedua penelitian ini menyebutkan bahwa kecerdasan interpersonal siswa memberi dampak yang signifikan terhadap hasil/ prestasi belajar siswa. Namun, tidak semua penelitian menyimpulkan hal yang sama. Penelitian Lindawati (2014) pada siswa kelas VII SMP Negeri 5 Madiun menyimpulkan bahwa tidak terdapat pengaruh yang signifikan antara kecerdasan interpersoanal siswa terhadap hasil belajar.

Keberagaman simpulan yang didapat dari penelitian terdahulu, mendorong dilakukannya penelitian ini untuk membandingkan model pembelajaran TAI dan NHT terhadap hasil belajar trigonometri siswa ditinjau dari Kecerdasan Interpersonal. Penelitian terdahulu membandingkan bagaimana perbedaan hasil belajar kedua model TAI dan NHT pada jenjang SMP. Sedangkan, pada jenjang SMA dilakukan terhadap materi IPA. Penelitian ini dilakukan pada jenjang SMA dengan materi pokok trigonometri. Trigonometri merupakan salah satu materi wajib di sekolah dengan topik yang sulit dipelajari siswa (Sarac, 2017). Sejalan dengan pernyataan May dan Courtney (Jaelani, 2017) yang menyebutkan bahwa materi trigonometri adalah komponen dari kurikulum matematika SMA yang penting (Ferrer, 2016). Mengungkapkan bahwa penguasaan trigonometri adalah salah satu prasyarat untuk menguasai materi matematika tingkat lanjut. Oleh karena itu, penelitian ini ingin mengetahui perbandingan hasil belajar trigonometri siswa dengan model TAl dan NHT. Slavin, (2005) menyebutkan bahwa model pembelajaran kooperatif TAI dan NHT sudah tergolong model pembelajaran kooperatif dengan level tinggi (Slavin, 2005)(Slavin, 2005). Salah satu sekolah yang memenuhi kriteria tersebut adalah SMA Negeri 1 Salatiga. Diharapkan pembelajaran dengan model TAI dan NHT di sekolah ini dapat mewujudkan proses pembelajaran yang lebih lebih aktif dan berfokus pada siswa.

\section{Metode}

Penelitian ini termasuk penelitian eksperimental dengan dua kelompok eksperimen yaitu kelompok eksperimen 1 yang menggunakan model pembelajaran kooperatif tipe Team Assisted Individualitation (TAI) dan kelompok eksperimen 2 yang menggunakan model Number Head Together (NHT). Penelitian ini tidak bisa mengendalikan semua variabel relevan yang dapat mempengaruhi hasil belajar matematika siswa, maka penelitian ini termasuk dalam penelitian eksperimental semu atau Quasi Experimental Research.

Populasi dalam penelitian ini adalah seluruh siswa kelas $X$ di SMA N 1 Salatiga Semester 2 Tahun Ajaran 2018/2019 yang terbagi dalam 12 kelas. Pengambilan sampel dilakukan secara acak dengan teknik cluster random sampling. Penelitian ini mengelompokkan populasi ke dalam 3 cluster yaitu jurusan IPA, IPS dan Bahasa. Dari 3 cluster tersebut dipilih 1 secara acak dan di dapat jurusan IPS. Selanjutnya siswa jurusan IPS dikelompokkan berdasar kelas masing-masing dan dipilih 2 kelas secara acak dan diperoleh siswa kelas X IPS 1 dan X IPS 2 sebagai sampel 
dalam penelitian ini. Penentuan model pembelajaran yang dikenakan pada masingmasing kelompok eksperimen dengan mempertimbangkan masukan dari guru yang mengampu kelas tersebut, dan akhirnya kelas $X$ IPS 1 sebagai kelompok eksperimen 1 dan kelas X IPS 2 sebagai kelompok eksperimen 2.

Pengumpulan data dalam penelitian ini menggunakan metode dokumentasi untuk memperoleh data nilai ulangan terakhir siswa, metode tes untuk mengukur hasil belajar matematika, metode angket untuk mengukur tingkat kecerdasan interpersonal yang dimiliki siswa dan metode observasi untuk mengukur keterlaksanaan kedua model pembelajaran.

Penelitian ini mencakup analisis deskripsi dan analisis inferensial baik untuk kondisi awal (uji keseimbangan kedua kelompok sampel) maupun kondisi akhir (uji hipotesis). Analisis deskripsi bertujuan untuk mendeskripsikan kondisi kedua kelompok sampel sedangkan analisis inferensial dilakukan untuk menyimpulkan kondisi populasi berdasarkan uji terhadap data sampel. Uji statistik inferensial meliputi uji independent sample t-test untuk menguji keseimbangan kedua kelompok sampel dan uji anava 2 jalan untuk menguji hipotesis penelitian. Adapun uji prasyarat normalitas dilakukan dengan uji Kolmogorov-smirnov dan uji homogenitas dengan uji Levene.

\section{Hasil dan Pembahasan}

Sebelum diberikan perbedaan perlakuan, dilakukan pengumpulan data kemampuan awal yang digunakan sebagai data untuk menguji keseimbangan kemampuan awal kedua kelas eksperimen. Selanjutnya diberikan perbedaan perlakuan dengan model pembelajaran kooperatif tipe TAl untuk kelas eksperimen 1 dan NHT untuk kelas eksperimen 2. Tahap terakhir adalah mengukuran hasil belajar kemampuan akhir dan kecerdasan interpersonal. Berikut uraian dari analisis data yang diperoleh dalam penelitian ini.

Perolehan data kemampuan awal untuk kedua kelas eksperimen dilakukan dengan cara pemberian tes awal dengan materi yang sebelumnya telah dipelajari oleh siswa. Hasilnya dapat dilihat dari Tabel 1. Data kemampuan awal 30 siswa di kelas ekperimen 1 dan 35 siswa di kelas eksperimen 2 menunjukan bahwa keduanya memiliki nilai minimum yang sama, yaitu 10. Adapun pencapaian pada kelas eksperimen 1 untuk nilai maksimum (77) dan rata-rata $(45,03)$ lebih baik dibandingkan dengan pencapaian nilai maksimal dan rata-rata di kelas eksperimen 2 yaitu 74 dan 36,40. Meskipun demikian standar deviasi kedua kelas hampir sama. Hal ini menunjukan bahwa kesenjangan kemampuan yang dimiliki kedua kelas cenderung sama.

Tabel 1.

Data Kemampuan Awal

\begin{tabular}{cccccc}
\hline & N & Mean & St.Dev & Min & Max \\
\hline Eks 1 & 30 & 45.03 & 18.823 & 10 & 77 \\
\hline Eks 2 & 35 & 36.40 & 18.137 & 10 & 74 \\
\hline \multicolumn{2}{l}{ Meskipun } & sudah & dilakukan & analisis
\end{tabular}

deskriptif kemampuan awal, namun untuk mengetahui keseimbangan kemampuan awal antara kedua kelompok sampel, maka perlu dilakukan uji inferensial dengan uji beda rerata. Terdapat 2 jenis uji beda rerata, yaitu uji parametrik untuk kelas sampel dengan populasi yang berdistribusi normal dan uji non parametrik untuk kelas sampel dengan populasi yang tidak berdistribusi normal. Oleh karena itu, perlu dilakukan uji normalitas untuk menentukan uji beda rerata yang digunakan. Hasil uji normalitas dapat dilihat dari Tabel 2. 
Tabel 2.

Uji Normalitas Kemampuan Awal

\begin{tabular}{|ccccc|}
\hline \multirow{2}{*}{} & \multirow{2}{*}{ Kelas } & \multicolumn{3}{c}{ Kolmogorov-Smirnov $^{\mathrm{a}}$} \\
\cline { 2 - 5 } & & Statistic & $\mathrm{df}$ & Sig. \\
\hline \multirow{2}{*}{ Pretest } & Eks 1 & .135 & 30 & .171 \\
\cline { 2 - 5 } & Eks 2 & .087 & 35 & $.200^{*}$
\end{tabular}

Uji normalitas untuk kedua kelas eksperimen menghasilkan nilai signifikan yang lebih dari 0,05 sehingga dapat disimpulkan bahwa kedua kelompok sampel masing-masing berasal dari populasi yang berdistribusi normal. Oleh karena itu, uji yang digunakan adalah uji parametrik yaitu Independent Sampel T-Test. Terdapat 2 jenis Independent Sampel T-Test, maka perlu dilakukan uji homgenitas. Hasil uji homogenitas sekaligus hasil uji Independent Sampel T-Test dapat dilihat dari Tabel 3. Pada Tabel 3, tampak bahwa uji homogenitas menghasilkan signifikan 0,720 (lebih dari 0,05), maka kedua kelompok sampel tersebut berasal dari populasi dengan variansi yang sama. Oleh karena itu, Independent Sampel T-Test yang digunakan adalah Independent Sampel T-Test Equal variances assumed. Uji ini menghasilkan signifikan sebesar 0,065 (lebih dari 0,05), sehingga dapat disimpulkan bahwa kedua kelompok eksperimen secara signifikan memiliki kemampuan awal yang sama (seimbang).

Tabel 3.

Uji Homogenitas dan Independent Sample T-Test

\begin{tabular}{|c|c|c|c|c|c|c|c|}
\hline \multicolumn{8}{|c|}{ Independent Samples Test } \\
\hline \multirow{2}{*}{\multicolumn{4}{|c|}{$\begin{array}{c}\text { Levene's Test for Equality } \\
\text { of Variances }\end{array}$}} & \multicolumn{4}{|c|}{ t-test for Equality } \\
\hline & & & & \multicolumn{4}{|c|}{ of Means } \\
\hline \multirow{7}{*}{ 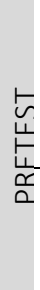 } & Eq. & & .7 & 1. & 63 & .0 & 8. \\
\hline & variances & 1 & 20 & 88 & & 65 & 6 \\
\hline & assumed & 2 & & & & & 3 \\
\hline & & 9 & & & & & \\
\hline & Eq. var not & & & 1. & 60 & .0 & 8. \\
\hline & assumed & & & 87 & .7 & 66 & 6 \\
\hline & & & & & & & 3 \\
\hline
\end{tabular}

Sesuai standar proses, pembelajaran terbagi ke dalam tiga tahap yaitu; kegiatan pendahuluan, kegiatan inti dan kegiatan penutup. Kegiatan pendahuluan kedua model secara umum yaitu menyiapkan peserta didik secara psikis dan fisik untuk mengikuti pembelajaran, memberi motivasi belajar peserta didik dengan penyampaian kebermanfaatan materi, memberikan pertanyaan yang mengaitkan pengetahuan sebelumnya dengan materi yang akan dipelajari, menjelaskan tujuan pembelajaran, menyampaikan cakupan materi dan penjelasan uraian kegiatan.

Prinsip tanggung jawab individu sebagai kontrol tercapainya pembelajaran masingmasing kedua model ini berbeda. Selama proses pembelajaran, guru memberikan pendampingan dan menginformasikan kepada setiap kelompok bahwa akan diadakan kuis di akhir pembelajaran pada pembelajaran TAI. Kuis ini dilakukan dan dinilai secara individu untuk mengetahui bagaimana siswa memahami materi dan sejauh mana pembelajaran tercapai.

Berbeda dengan model pembelajaran kooperatif tipe TAl, prinsip tanggung jawab individu dalam pembelajaran NHT dilakukan dengan pemanggilan nomor siswa untuk menjelaskan di depan kelas. Penentuan kelompok dan siswa yang mendapat bagian menjelaskan dilakukan secara acak, maka tidak ada yang mengetahui siapa yang mendapat tanggung jawab untuk menjelaskan di depan kelas.

Berdasarkan observasi beberapa siswa yang mendapat bagian menjelaskan di depan kelas kurang memahami materi yang diajarkan sehingga tidak melakukan tanggung jawabnya secara baik. Siswa yang dikenai pembelajaran TAl bertanggung jawab dalam mengerjakan kuis dikarenakan nilai yang diperoleh adalah untuk individu, sedangkan siswa yang dikenai pembelajaran NHT kurang termotivasi dalam pembelajaran dikarenakan hanya dilakukan pemanggilan nomor secara acak tanpa ada 
tanggung jawab untuk memperoleh nilai individu.

Selama proses pengambilan data, peneliti bertindak sebagai guru sedangkan guru mata pelajaran matematika dan dosen pendidikan matematika sebagai observer untuk menilai keterlaksanaan model. Hasil observasi tersebut dapat dilihat pada Tabel 4 yang menyebutkan bahwa nilai observasi kedua model lebih dari $80 \%$ dan berada dalam kategori sangat baik.

Tabel 4.

Hasil Observasi Pembelajaran

\begin{tabular}{|c|c|c|}
\hline \multirow[t]{2}{*}{ Aspek } & \multicolumn{2}{|c|}{$\begin{array}{l}\text { Persentase Hasil } \\
\text { Penilaian }\end{array}$} \\
\hline & TAI & $\mathrm{NHT}$ \\
\hline $\begin{array}{l}\text { Kesesuaian RPP dengan } \\
\text { Kurikulum } 2013\end{array}$ & 89 & 90 \\
\hline $\begin{array}{l}\text { Kesesuaian Pembelajaran dengan } \\
\text { Prinsip RPP Kurikulum } 2013\end{array}$ & 84 & 82 \\
\hline $\begin{array}{l}\text { Kesesuaian Pembelajaran dengan } \\
\text { Model Pembelajaran Kooperatif }\end{array}$ & 85 & 83 \\
\hline Penguasaan Kelas & 83 & 82 \\
\hline Penguasaan Materi & 85 & 85 \\
\hline $\begin{array}{l}\text { Rata-rata Pelaksanaan } \\
\text { Pembelajaran }\end{array}$ & 85,2 & 84,2 \\
\hline Kategori & $\begin{array}{c}\text { Sangat } \\
\text { Baik }\end{array}$ & $\begin{array}{l}\text { Sanga } \\
\text { t Baik }\end{array}$ \\
\hline
\end{tabular}

Berdasarkan rekapitulasi hasil observasi

pada Tabel 4, tampak dalam hal perancangan, kedua model telah dirancang sesuai dengan prinsip kurikulum. Adapun dari segi keterlaksanaan model pembelajaran, keduanya juga memperoleh persentase penilaian yang hampir sama baik dari segi keterlaksanaan pembelajaran, penguasaan materi maupun penguasaan kelas.

Penelitian ini juga mengukur pencapaian hasil belajar dari penerapan kedua model tersebut. Data nilai akhir (nilai posttest) yang diperoleh kedua kelompok sampel dapat dilihat dari Tabel 5.
Tabel 5.

Deskripsi Hasil Belajar Matematika Pada Kondisi Akhir

\begin{tabular}{|c|c|c|c|c|c|}
\hline & $\mathrm{N}$ & Mean & Std.Deviation & $\begin{array}{c}\mathrm{Mi} \\
\mathrm{n}\end{array}$ & $\begin{array}{c}\mathrm{Ma} \\
\mathrm{x}\end{array}$ \\
\hline EKS & 3 & 70.4 & 14.115 & 4 & 9 \\
\hline 1 & 0 & 7 & & 0 & 0 \\
\hline EKS & 3 & 56.6 & 13.173 & 3 & 8 \\
\hline 2 & 5 & 6 & & 2 & 2 \\
\hline
\end{tabular}

kemampuan akhir 30 peserta didik dari kelas eksperimen 1 yang diberi model pembelajaran kooperatif tipe TAI menghasilkan nilai minimum dan nilai maksimum yang lebih baik dibandingkan dengan kelas eksperimen 2 yang diberi model pembelajaran kooperatif tipe NHT.

Selain mengukur hasil belajar, pada penelitian ini juga dilakukan pengukuran tingkat kecerdasan interpersonal. Pengukuran tingkat kecerdasan interpersonal siswa dilakukan dengan cara pengisian angket kecerdasan interpersonal. Rekapitulasi rata-rata hasil belajar yang sudah dikelompokan berdasarkan tingkat kecerdasan interpersonal dapat dilihat pada Tabel 6.

Tabel 6.

Nilai Rata - Rata Kondisi Akhir Berdasarkan Kecerdasan Interpersonal

\begin{tabular}{|c|c|c|c|c|}
\hline \multirow{2}{*}{$\begin{array}{c}\text { Nilai pada } \\
\text { Kelas }\end{array}$} & \multicolumn{3}{|c|}{ Kecerdasan Interpersonal } & \multirow{2}{*}{$\begin{array}{c}\text { Rata- } \\
\text { rata } \\
\text { Total }\end{array}$} \\
\hline & Tinggi & Sedang & Rendah & \\
\hline TAl & 67,25 & 76 & 68,38 & 70,47 \\
\hline NHT & 52,88 & 56,08 & 59,36 & 56,66 \\
\hline Rata-rata & 61,50 & 64,74 & 62,64 & \\
\hline
\end{tabular}

Berdasarkan Tabel 6, diperoleh data bahwa peserta didik dengan tingkat kecerdasan interpersonal tinggi, sedang dan rendah yang dikenai model pembelajaran kooperatif tipe TAI masing-masing lebih tinggi dibanding nilai ratarata peserta didik yang dikenai model pembelajaran kooperatif tipe NHT. Adapun nilai rata-rata peserta didik dengan tingkat kecerdasan interpersonal sedang adalah 64,74 lebih baik dibandingkan nilai rata-rata peserta 
didik dengan tingkat kecerdasan interpersonal rendah dan tinggi yang masing-masing adalah 62,64 dan 61,50. Meskipun demikian untuk menentukan apakah perbedaan hasil belajar tersebut signifikan atau tidak, maka dilakukan uji inferensial.

Melihat karakteristik data, maka uji statistik yang dapat digunakan adalah uji anava 2 jalan. Oleh karena itu perlu dilakukan 2 uji prasyarat yaitu normalitas dan homogenitas. Hasil uji normalitas data kemampuan akhir dapat dilihat pada Tabel 7.

Tabel 7.

Uji Normalitas Data Kemampuan Akhir

\begin{tabular}{|c|c|c|c|c|}
\hline & \multirow[t]{2}{*}{ KELAS } & \multicolumn{3}{|c|}{ Kolmogorov-Smirnov ${ }^{\mathrm{a}}$} \\
\hline & & Statistic & Df & Sig. \\
\hline \multirow{5}{*}{ 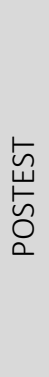 } & Eks 1 & .136 & 30 & .162 \\
\hline & Eks 2 & .104 & 35 & .200 \\
\hline & Tinggi & .189 & 20 & .061 \\
\hline & Sedang & 102 & 23 & $\begin{array}{c}200 \\
*\end{array}$ \\
\hline & Rendah & .115 & 22 & $\begin{array}{c}200 \\
*\end{array}$ \\
\hline
\end{tabular}

Uji normalitas nilai posttest untuk masingmasing kelas eksperimen dan tingkat kecerdasan interpersonal menggunakan Kolmogorov-Smirnov menghasilkan nilai signifikasi yang semuanya lebih dari 0,05 yang artinya nilai posttest untuk masing-masing kelompok sampel berasal dari populasi yang berdistribusi normal. Selanjutnya dilakukan uji homogenitas untuk mengetahui apakah sampel berasal dari populasi dengan variansi yang sama. Uji homogenitas dilakukan dua kali, yang pertama antara data nilai posttest di antara kedua kelompok kelas dan di antara kategori pada kecerdasan interpersonal. Hasil uji homogenitas ini dapat dilihat dari Tabel 8. Nilai signifikan hasil uji homogenitas untuk nilai posttest antara kedua kelas eksperimen dan antara kategori kecerdasan interpersonal menghasilkan nilai signifikan yang lebih dari
0,05 maka dapat disimpulkan bahwa keduanya berasal dari populasi yang homogen.

Tabel 8.

Uji Homogenitas Data Kemampuan Akhir

\begin{tabular}{|c|c|c|c|c|}
\hline & POSTEST & & & \\
\hline & $\begin{array}{l}\text { Levene } \\
\text { Statistic }\end{array}$ & df1 & $\mathrm{df2}$ & Sig. \\
\hline $\begin{array}{l}\text { Kedua } \\
\text { Kelas }\end{array}$ & .028 & 1 & 63 & .868 \\
\hline Kecerdasan & 1.062 & 2 & 62 & .352 \\
\hline
\end{tabular}

Syarat-syarat dalam melakukan uji Anava yaitu uji normalitas dan uji homogenitas sudah terpenuhi. Oleh karena itu, untuk menguji hipotesis dalam penelitian ini dilakukan dengan uji anava dua jalan dengan sel tak sama yang hasilnya dapat dilihat dari Tabel 9.

Tabel 9.

Uji Analisis Variansi Dua Jalan

\begin{tabular}{|c|c|c|c|c|c|}
\hline \multicolumn{6}{|c|}{ Dependent Variable: POSTEST } \\
\hline \multirow[t]{5}{*}{ Source } & Type & $\bar{d}$ & Mean & $\bar{F}$ & $\overline{\mathrm{Si}}$ \\
\hline & III Sum & $f$ & Square & & g. \\
\hline & of & & & & \\
\hline & Square & & & & \\
\hline & S & & & & \\
\hline \multirow{2}{*}{$\begin{array}{l}\text { Corrected } \\
\text { Model }\end{array}$} & 3766.8 & 5 & 753.3 & 4.04 & .0 \\
\hline & a & & & & 03 \\
\hline \multirow[t]{2}{*}{ Intercept } & 24815 & 1 & 24815 & 133 & .0 \\
\hline & 8.1 & & 8.1 & 2.1 & 00 \\
\hline \multirow[t]{2}{*}{ KELAS } & 3225.5 & 1 & 3225.5 & 17.3 & .0 \\
\hline & & & & 1 & 00 \\
\hline \multirow[t]{2}{*}{ TING_KI } & 375.2 & 2 & 187.6 & 1.00 & .3 \\
\hline & & & & 7 & 71 \\
\hline \multirow{2}{*}{$\begin{array}{l}\text { KELAS * } \\
\text { TING_KI }\end{array}$} & 319. & 2 & 159.5 & .856 & .4 \\
\hline & & & & & 30 \\
\hline \multirow[t]{2}{*}{ Error } & 10991. & 5 & 186.2 & & \\
\hline & 1 & 9 & & & \\
\hline \multirow[t]{2}{*}{ Total } & 27299 & 6 & & & \\
\hline & 5.0 & 5 & & & \\
\hline \multirow{2}{*}{$\begin{array}{l}\text { Corrected } \\
\text { Total }\end{array}$} & 14757. & 6 & & & \\
\hline & 9 & 4 & & & \\
\hline
\end{tabular}

Pada Tabel 9 tampak bahwa pada variabel model pembelajaran, nilai signifikan tertulis .000 (yang berarti mendekati nol dan artinya kurang dari 0,05). Hal ini menunjukkan bahwa terdapat perbedaan rata-rata yang signifikan antara hasil belajar peserta didik yang diberi 
model pembelajaran kooperatif tipe TAI dan NHT. Oleh karena itu untuk menentukan model pembelajaran kooperatif tipe manakah yang menghasilkan hasil belajar yang lebih baik, dapat dilihat pada rata-rata keduanya. Berdasarkan Tabel 6 tampak bahwa nilai ratarata hasil belajar siswa yang dikenai model pembelajaran kooperatif tipe TAI $(70,47)$ lebih tinggi dari pada rata-rata hasil belajar siswa yang dikenai model pembelajaran kooperatif tipe NHT $(56,66)$. Dengan demikian dapat disimpulkan bahwa model pembelajaran kooperatif tipe TAl secara siginifikan menghasilkan hasil belajar yang lebih baik dibandingkan model pembelajaran kooperatif tipe NHT.

Hasil uji pada tingkat kecerdasan interpersonal memperoleh nilai signifikan sebesar 0,371 (lebih dari 0,05) yang berarti bahwa tidak terdapat perbedaan hasil belajar yang signifikan antara tingkat kecerdasan interpersonal. Demikian juga dengan nilai signifikasi pada interaksi antara model pembelajaran kooperatif dengan tingkat kecerdasan interpersonal sebesar 0,430 (lebih dari 0,05) sehingga dapat disimpulkan bahwa tidak ada interaksi antara model pembelajaran kooperatif dengan tingkat kecerdasan interpersonal terhadap hasil belajar siswa. Hal ini berarti penerapan TAI secara signifikan menghasilkan hasil belajar di setiap tingkatan kecerdasan interpersonal. Selain itu, baik dalam TAI maupun NHT tidak ada perbedaan Hasil Belajar dari tingkat kecerdasan interpersonal.

Hasil penelitian ini telah menunjukkan bahwa penerapan TAl pada materi wajib trigonometri di kelas X SMA N 1 Salatiga secara signifikan menghasilkan hasil belajar yang lebih baik dibandingkan NHT. Kesimpulan ini sama dengan hasil penelitian Antoro \& Utomo
(2016). Model pembelajaran yang digunakan oleh guru adalah salah satu faktor eksternal yang dapat mempengaruhi hasil belajar. Penerapan model pembelajaran yang berbeda dapat memberikan dampak yang berbeda pula terhadap hasil belajar yang diperoleh. Pada model pembelajaran kooperatif tipe TAl, siswa diberikan tes di akhir pembelajaran yang dikerjakan secara mandiri sebagai nilai individu. Adanya tes pada pembelajaran TAI ini ternyata mempengaruhi bagaimana siswa belajar untuk mendalami materi secara lebih dalam, baik di dalam kelompok ataupun secara mandiri. Timbul motivasi dalam diri siswa untuk memperoleh hasil yang maksimal ketika tes di setiap akhir pembelajaran. Hal ini sejalan dengan hasil penelitian (Aini, 2016) yang menyatakan bahwa semakin baik motivasi yang ada pada diri siswa akan semakin tinggi pula hasil belajar yang diperoleh.

Motivasi yang sama tidak begitu tampak dominan di NHT. Berdasarkan hasil observasi saat pelaksanaan model, tidak semua siswa yang terpilih acak untuk maju mewakili kelompok menguasai materi hasil diskusi. Ketidakberhasilan siswa yang terpilih secara acak dipandang sebagai hal yang biasa, baik oleh siswa yang bersangkutan ataupun teman satu kelompok juga teman kelompok lain. Hal ini yang diduga membuat siswa kurang optimal dalam proses diskusi. Selain itu, tidak adanya pencatatan skor kelompok diduga juga sebagai salah satu faktor pemicu kurang seriusnya siswa dalam menyikapi proses pemanggilan nomor (karena tidak adanya unsur kompetisi antar kelompok). Slavin (2005) mengatakan bahwa adanya pencatatan skor dalam pembelajaran kooperatif menimbulkan persaingan yang sehat dan akan memicu motivasi siswa dalam 
kelompok untuk belajar dan memahami materi dengan lebih baik.

Hasil penelitian untuk rumusan masalah yang ketiga menunjukkan bahwa tidak terdapat perbedaan hasil belajar yang signifikan dari ketiga tingkat kecerdasan interpersonal. Hasil yang sama ditemukan dalam penelitian Lindawati (2014) yang menyatakan bahwa tidak ada perbedaan prestasi belajar siswa antara tingkat kecerdasan interpersonal.

Hipotesis awal penelitian ini menduga bahwa siswa yang memiliki kecerdasan interpersonal tinggi akan lebih mudah dalam mencerna pembelajaran karena menurut teori, siswa yang mempunyai kecerdasan interpersonal yang tinggi lebih akan lebih mudah dalam melakukan diskusi dalam kelompok. Akan tetapi, hasil observasi selama penerapan kedua model menunjukkan bahwa siswa yang memiliki kecerdasan interpersonal tinggi, sedang dan rendah sama-sama tidak mengalami kesulitan dalam diskusi dikarenakan mereka sudah mengenal satu sama lain. Selain itu, adanya sistem pembelajaran menggunakan Unit Kegiatan Belajar Mandiri (UKBM) memungkinkan siswa untuk belajar secara mandiri di rumah sehingga tidak begitu bergantung pada proses diskusi dalam kelompok. Proses diskusi hanya bersifat klarifikasi atas pengetahuan yang telah dikonstruksi masing-masing. Oleh karena itu, siswa dengan tingkat kecerdasan interpersonal tinggi, sedang dan rendah memiliki kemampuan yang sama dalam penguasaan materi. Dengan kata lain, masing-masing siswa dengan tingkat kecerdasan interpersonal dapat beradapatasi dalam pembelajaran. Hal ini sesuai dengan Lindawati (2014) yang mengatakan bahwa adanya adaptasi dari masing-masing kategori kecerdasan interpersonal mengakibatkan tidak adanya perbedaan hasil belajar siswa yang memiliki kecerdasan tinggi dengan siswa yang memiliki kecerdasan interpersonal rendah.

Hasil penelitian antara penerapan model pembelajaran kooperatif ditinjau dari tingkat kecerdasan interpersonal terhadap hasil belajar menyimpulkan bahwa tidak terdapat interaksi antara model pembelajaran dengan tingkat kecerdasan interpersonal terhadap hasil belajar siswa. Hubungan sosial di dalam kelas yang sudah terjalin akrab, membuat siswa masingmasing dalam kelompoknya dapat berdiskusi dengan baik dan tidak mengalami kesulitan. Terjalinnya keakraban yang sudah mengenal satu sama lain ini membuat siswa mudah dalam berdiskusi. Menurut Johnson dan Johnson (Lestari, 2016: 17), kelompok siswa yang sudah saling mengenal menciptakan hubungan sosial yang baik sehingga masing-masing anggota kelompok bersedia memperhatikan dan menghargai satu sama lain, dengan kata lain setiap siswa yang ada dalam kelompok itu mendapat dukungan sosial yang baik.

Selain itu, tidak adanya interaksi antara model pembelajaran dengan tingkat kecerdasan interpersonal juga bisa disebabkan karena adanya kolaborasi yang baik dari masing-masing individu. Ini berarti siswa dengan tingkat kecerdasan interpersonal tinggi, sedang dan rendah sama-sama mempunyai hubungan sosial dan dukungan sosial yang baik dan terdorong untuk berkolaborasi secara maksimal tanpa ada kesulitan dalam diskusi kelompok karena sudah mengenal satu sama lain. Hal ini sejalan dengan penelitian yang dilakukan oleh Damayanti \& Apriyanto (2017) yang mengatakan bahwa adanya hubungan yang baik dalam pertemanan sebaya akan berakibat positif terhadap pembelajaran yang efektif. 


\section{Penutup}

Penelitian ini telah membuktikan bahwa adanya perbedaan tingkat kecerdasan interpersonal tidak signifikan berpengaruh terhadap hasil belajar dikarenakan sudah terciptanya hubungan interpersonal siswa dalam satu kelas. Oleh karena itu, disarankan bagi guru khususnya wali kelas untuk dapat melakukan kegiatan yang bersifat untuk menumbuhkan rasa solidaritas, persaudaraan yang didasari empati dan saling menghargai agar tercipta hubungan interpersonal yang baik antar siswa dalam satu kelas.

\section{Daftar Pustaka}

Afriansyah, E. A. (2015). Qualitative Became Easier with ATLAS.ti. International Seminar on Mathematics, Science, and Computer Science Education MSCEIS 2015 Universitas Pendidikan Indonesia.

Aini, Q. (2016). Pengaruh Motivasi Belajar Intrinsik Dan Ekstrinsik Terhadap Prestasi Belajr Ekonomi Di SMA NW Pancor Lombok Timur NTB. Ganec Swara, 10(2), 91-96.

Anggoro, R. P. (2015). Pengaruh Pembelajaran Kooperatif Tipe NHT dan TAl dengan Pendekatan Kontekstual terhadap Partisipasi dan Prestasi Belajar Matematika. 10, 71-78.

Antoro, Y. D., \& Utomo, S. B. (2016). Pengaruh Model Pembelajaran Team Assisted Individualization (TAI) Dan Numbered Heads Together (NHT) Terhadap Prestasi Belajar Siswa Ditinjau Dari Kemampuan Memori Pada Materi Pokok Sistem Koloid Kelas Xi Sma Negeri 3 Boyolali. 5(3), 1-8.
Asmani, M. J. (2012). Buku Panduan Internalisasi Pendidikan Karakter di Sekolah. Yogyakarta: Diva Press.

Damayanti, S., \& Apriyanto, M. T. (2017). Pengaruh Model Pembelajaran Kooperatif Tipe TGT (Teams Games Tournament) Terhadap Hasil Belajar Matematika. 2348, 235-244

Eka, S., Handayani, Nuriah, T., Sarkadi (2017). Pengaruh Model Pembelajaran dan Kecerdasan Interpersonal Terhadap Hasil Belajar Sejarah Siswa SMA Negeri 3 Kabupaten Tangerang. 6(1), 19-28.

Fajriani, \& Masni, E. D. (2017). Pengaruh Kecerdasan Interpersonal Terhadap Hasil Belajar Matematika Siswa. 2, 63-73.

Ferrer, F. P. (2016). Investigating Students' Learning Difficulties In. 2(1), 310-324.

Firdaus, D. A., \& Afriansyah, E. A. (2016). Pembelajaran Kooperatif Tipe Team Assisted Individually untuk Meningkatkan Kemampuan Pemahaman Matematis Siswa Sekolah Menengah Pertama. Jurnal Pendidikan Matematika RAFA, 2(1), 104122.

Gardner, H. (2003). Multiple Intelligences: Kecerdasan Majemuk Teori dalam Praktek (Dr. Lyndon Saputra, ed.). Batam Centre.

Hanggara, Y., \& Jafri, F. (2016). Keefektifan Model Pembelajaran Kooperatif Numbered Heads Together (NHT) Dan Teams Assisted Individualization (TAI) Ditinjau Dari Hasil Belajar. 9(1), 1-5.

Jaelani, A. (2017). Kesalahan jawaban tes trigonometri mahasiswa pendidikan matematika semester pertama. 3(November), 1-13.

Lagur, D. S., Makur, A. P., \& Ramda, A. H. (2018). Pengaruh Model Pembelajaran Kooperatif Tipe Numbered Head Together 
(NHT) terhadap Kemampuan Komunikasi Matematis. Mosharafa: Jurnal Pendidikan Matematika, 7(3), 357-368.

Lestari, V. (2016). Hubungan Antara Dukungan Sosial Orangtua Dengan Penyesuaian Diri Remaja Dengan Orangtua Bercerai.

Lie, Anita (2002). cooperative Learning: mempraktikkan cooperative learning di ruang-ruang kelas. Jakarta: Grasindo.

Lindawati, K. (2014). Pengaruh Kecerdasan Interpersonal Terhadap Prestasi Belajar Matematika Siswa Kelas VII SMPN 5 Madiun Dalam Pembelajaran Kooperatif Tipe TAl (Team Assisted Individuaization).

Megawati, Y. D. N., \& Sari, A. R. (2012). Model Pembelajaran Kooperatif Tipe Team Assisted Individualization (TAI) Dalam Meningkatkan Keaktifan Siswa Dan Hasil Belajar Akuntansi Siswa Kelas XI IPS 1 SMA Negeri 1 Banjarnegara Tahun Ajaran 2011/2012. X(1), 162-180.

Menteri Pendidikan dan Kebudayaan Republik Indonesia. (2016). Peraturan Menteri Pendidikan dan Kebudayaan Nomor 22 Tahun 2016 Tentang Standar Proses Pendidikan Dasar dan Menengah.

Pendidikan, M., Kebudayaan, D. A. N., \& Indonesia, R. (2016). Peraturan Menteri Pendidikan Dan Kebudayaan Nomor 22 Tahun 2016 Tentang Standar Proses Pendidikan Dasar Dan Menengah.

Pradipta, E., Soekardjo, J. S., Retno, S., \& Ariani, D. (2013). Studi Komparasi Penggunaan Metode Pembelajaran Team Assisted Individualization (TAI) dan Numbered Heads Together (NHT) Terhadap Prestasi Belajar Siswa dengan Memperhatikan Aktivitas Belajar Siswa Pada Materi Pokok Kelarutan dan Hasil Kali Kelarutan Kelas. 2(2), 31-37.

Putri, K. C., \& Sutriyono. (2018). Pengaruh Metode Pembelajaran STAD Terhadap
Hasil Belajar Matematika pada Siswa Kelas VIII. Mosharafa: Jurnal Pendidikan Matematika, 7(2), 295-306.

Riswanto, A. (2016). Pengaruh Model Pembelajaran Kooperatif Tipe Team Assisted Individualization Terhadap Motivasi Belajar Mahasiswa. Mosharafa: Jurnal Pendidikan Matematika, 5(3), 293304.

Said, A., \& Budimanjaya, A. (2015). 95 Strategi Mengajar Multiple Intelligences: Mengajar Sesuai Kerja Otak dan Gaya Belajar Siswa. Jakarta: Kencana.

Sarac, A. (2017). The Relationship between Teacher Efficacy, and Students' Trigonometry Self-Efficacy and Achievement. 18, 66-83.

Shoimin, A. (2014). 68 Model Pembelajaran Inovatif Dalam Kurikulum 2013. Yogyakarta: Ar-Ruzz Medi.

Slavin, R. E. (2005). Cooperative Learning: Teori, riset dan praktik. Bandung: Nusa Media.

Suherman, E. (2001). Strategi Pembelajaran Matematika Kontemporer. Bandung: JICAUniversitas Pendidikan Indonesia.

\section{Riwayat Hidup Penulis}

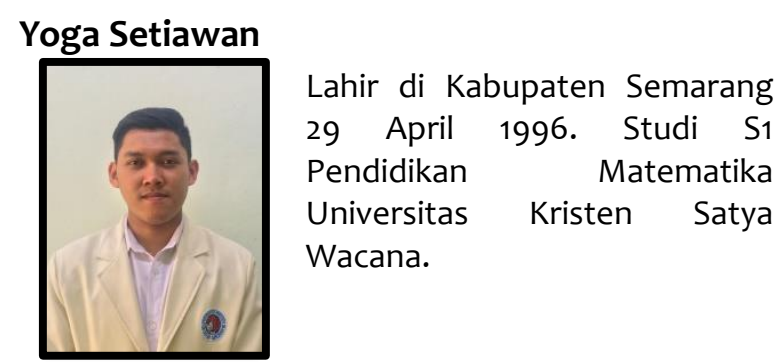

\section{Erlina Prihatnani, S.Si., M.Pd.}

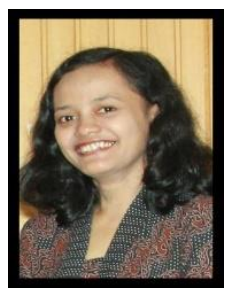

Lahir di Purworejo, 10 Agustus 1984. Dosen Progam Studi Pendidikan Matematika Universitas Kristen Satya Wacana, Salatiga memperoleh gelar S1 Matematika FSM di Universitas Kristen Satya Wacana, kemudian melanjutkan studi dan memperoleh gelar S2 di Unversitas Sebelas Maret Surakarta. 